\title{
Effect of the lipase inhibitor orlistat and of dietary lipid on the absorption of radiolabelled triolein, tri- $\gamma$-linolenin and tripalmitin in mice
}

\author{
BY DOROTHEA ISLER, CHRISTINE MOEGLEN, NIGEL GAINS \\ AND MARCEL K. MEIER \\ Pharma Division, Preclinical Research, F. Hoffmann-La Roche Ltd, CH-4002 Basel, Switzerland
}

(Received 8 November 1993 - Revised 12 September 1994 - Accepted 7 October 1994)

\begin{abstract}
Orlistat, a selective inhibitor of gastrointestinal lipases, was used to investigate triacylglycerol absorption. Using mice and a variety of emulsified dietary lipids we found that the absorption of radiolabelled tripalmitin (containing the fatty acid 16:0), but not of triolein $(18: 1 n-9)$ or tri- $\gamma$-linolenin (18:3n-6), was incomplete from meals rich in esterified palmitate. Further, the absorption of radiolabelled tri- $\gamma$-linolenin, from both saturated and unsaturated dietary triacylglycerols, was 1-3- to 2fold more potently inhibited by orlistat than that of triolein and tripalmitin. These radiolabelled triacylglycerols, which have the same fatty acid in all three positions, may not always be accurate markers of the absorption of dietary triacylglycerols. Orlistat was more effective at inhibiting the absorption of radiolabelled triacylglycerols with which it was codissolved than those added separately, which indicates that equilibration between lipid phases in the stomach may not always be complete. The saturation of the dietary lipid had little or no effect on the potency of orlistat. Orlistat provides a novel approach for studying the role of triacylglycerol hydrolysis in the overall process of triacylglycerol absorption.
\end{abstract}

Lipase inhibitor: Triacylglycerol: Absorption: Mice

Dietary triacylglycerols can only be absorbed after they have been hydrolysed by gastrointestinal lipases to give fatty acids and monoacylglycerols (Nelson \& Ackman, 1988). In vitro, different triacylglycerols are hydrolysed at different rates; for example, triacylglycerols that contain less common or long-chain, saturated fatty acids are hydrolysed more slowly (Brockerhoff, 1970; Lawson \& Hughes, 1988; Bergstedt et al. 1990, 1991; Yang et al. 1990). In vivo the rate of fatty acid absorption depends on the physicochemical properties both of the individual fatty acids and of the dispersion that they form with the fats and other components in the diet (Ockner et al. 1972; Carey et al. 1983). The site of absorption has also been found to depend on the rate of absorption; triacylglycerols that are more slowly absorbed, for example those with long-chain, saturated fatty acids, tend to have a more distal site of absorption (Bergstedt et al. 1990, 1991). However, the large excess of both pancreatic (EC 3.1.1.3) and carboxyl ester lipase (EC 3.1.1.13) combined with the large surface area of the intestine ensure that even alkyl esters with low rates of hydrolysis are efficiently absorbed (Nelson \& Ackman, 1988; Chen et al. 1989; Yang et al. 1990).

Orlistat is a selective and potent inhibitor of lipases that acts solely in the intestinal lumen and does not inhibit the absorption of oleic acid (Borgström, 1988; Hadvary et al. 1988,

Address for correspondence: Dr D. Isler, F. Hoffmann-La Roche Ltd, Bau 60/403, Grenzacherstr. 124, CH-4002 Basel, Switzerland. 
1991; Fernandez \& Borgström, 1989; Lüthi-Peng et al. 1992). It inactivates the lipase by reacting covalently with the serine (Ser- ${ }^{152}$ ) in the active site. Orlistat has been shown to reduce hypertriacylglycerolaemia and obesity in animals (Hogan et al. 1987; Meier et al. 1991) and its effectiveness in man is undergoing clinical investigation (Drent et al. 1992; Hauptmann et al. 1992).

Our aim was to use orlistat in order to study the relative efficiency with which a variety of emulsified dietary lipids are absorbed in mice, and in particular to answer the following questions : first, whether radiolabelled triacylglycerols, such as triolein (containing the fatty acid 18:1n-9), tri- $\gamma$-linolenin $(18: 3 n-6)$ and tripalmitin $(16: 0)$, are suitable markers for the absorption of dietary triacylglycerols; and second, under conditions where triacylglycerol hydrolysis is impaired, whether the absorption of these radiolabels is affected by the nature of the dietary fat in which they are dissolved.

\section{MATERIALS AND METHODS}

Materials

$\left[{ }^{14} \mathrm{C}\right]$ Triolein (glycerol-tri[1-1 $\left.{ }^{14} \mathrm{C}\right]$ oleate, $2 \mathrm{GBq} / \mathrm{mmol}$ ), $\left[{ }^{14} \mathrm{C}\right]$ tripalmitin (glycerol-tri[ $\left[1-{ }^{14} \mathrm{C}\right]-$ palmitate, $2 \mathrm{GBq} / \mathrm{mmol}),\left[1-{ }^{14} \mathrm{C}\right]$ oleic acid $(2 \mathrm{GBq} / \mathrm{mmol})$ and $\left[{ }^{14} \mathrm{C}\right]$ dioleoyl-phosphatidylcholine (1,2-di[1-14 $\mathrm{C}]$ oleyl-3-phosphatidylcholine, $4 \mathrm{GBq} / \mathrm{mmol}$ ) were obtained from Amersham International plc (CH-8058, Zürich, Switzerland), $\left[{ }^{3} \mathrm{H}\right]$ triolein (glycerol-tri[9,10${ }^{3} \mathrm{H}$ ]oleate, $992 \mathrm{GBq} / \mathrm{mmol}$ ) from NEN Research Products Du Pont de Nemours International S.A., CH-8058 Zürich, Switzerland, and $\left[{ }^{14} \mathrm{C}\right]$ tri- $\gamma$-linolenin (glycerol-tri$\left[1-{ }^{14} \mathrm{C}\right]-6,9,12$-octadecatrienoate, $\left.7 \mathrm{GBq} / \mathrm{mmol}\right)$ was prepared by $\mathrm{Dr} H$. Harder at F. Hoffmann-La Roche, Basel, Switzerland. Briefly, $\left[{ }^{14} \mathrm{C}\right]$ tri- $\gamma$-linolenic acid was prepared by treating 1-chloro-5,8,11-heptadecatriene with Rieke's magnesium (Rieke \& Bales, 1974) and allowing the resulting Grignard intermediate to absorb ${ }^{14} \mathrm{CO}_{2} ;\left[{ }^{14} \mathrm{C}\right]$ tri- $\gamma$-linolenin was prepared by reacting the $\left[{ }^{14} \mathrm{C}\right]$ tri- $\gamma$-linolenic acid with glycerol in the presence of dimethylaminopyridine and dicyclohexylcarbodiimide. The $\left[{ }^{14} \mathrm{C}\right]$ tri- $\gamma$-linolenin was stored, in portions sufficient for one experiment, in sealed ampoules under Ar. Radioactive purity was checked by TLC using precoated silica-gel plates (HPTLC 60; Merck (Schweiz) AG, CH-8029 Zürich, Switzerland) and di-isopropylether-heptane-acetic acid (48:32:1.6) for triacylglycerols, chloroform-methanol-acetic acid-water $(65: 50: 4: 1)$ for phosphatidylcholine, and heptane-isopropyl ether-acetic acid $(60: 40: 4)$ for oleic acid. Radioactive purity was at least $97 \%$. $\left[1,2-{ }^{3} \mathrm{H}\right]$ polyethyleneglycol 4000 was from NEN Research Products.

Linseed oil was from a local pharmacy, olive and sunflower oils, cream and skimmed milk powder were from a supermarket, palm and coconut oils were from Tensochema $A G$, Zürich, Switzerland, borage oil was from Roche Lipid Technology, Heanor, Derbyshire and egg phosphatidylcholine was from Lipid Products, South Nutfield, Surrey. Orlistat (Ro 18-0647/002, MW 496) was obtained by chemical synthesis (Barbier \& Schneider, 1987). All other reagents were of analytical grade or the purest available.

\section{Animals}

Female, MORO (Ibm), albino mice (about $25 \mathrm{~g}$; twenty to thirty mice per experiment) were maintained on chow (Kliba 25-331; Klibamühle, Kaiseraugst, Switzerland) and water ad lib. They were kept individually in wire-mesh cages under a $12 \mathrm{~h}$ light $-12 \mathrm{~h}$ dark cycle.

\section{Preparation of the test meals}

The radiolabelled triacylglycerols, with or without orlistat, were dissolved in the cream and in the plant oils, under a stream of $\mathrm{N}_{2}$, by stirring for about $30 \mathrm{~min}$ at room temperature (at $65^{\circ}$ for $\left[{ }^{14} \mathrm{C}\right]$ tripalmitin) to give about $0.037 \mathrm{MBq} / \mathrm{g}$ plant oil and cream fat. 
Table 1. Approximate fatty acid composition ( $\mathrm{g} / 100 \mathrm{~g}$ total fatty acids), iodine values and melting points $\left(^{\circ}\right)$ of the dietary fats

\begin{tabular}{|c|c|c|c|c|c|c|c|}
\hline & $\begin{array}{l}\text { Palm } \\
\text { oil }^{*} \dagger\end{array}$ & $\begin{array}{l}\text { Coconut } \\
\text { oilt }\end{array}$ & Cream*t & $\begin{array}{l}\text { Olive } \\
\text { oil }^{*}\end{array}$ & $\begin{array}{l}\text { Sunflower- } \\
\text { seed oil* }\end{array}$ & $\begin{array}{c}\text { Borage } \\
\text { oilt }\end{array}$ & $\begin{array}{l}\text { Linseed } \\
\text { oil }^{*}\end{array}$ \\
\hline \multicolumn{8}{|l|}{ Polyunsaturated } \\
\hline Linoleic & 10 & 2 & 2 & 8 & 69 & 36 & 15 \\
\hline Linolenic & 1 & 1 & 2 & 1 & 0 & 23 & 53 \\
\hline \multicolumn{8}{|c|}{ Monounsaturated } \\
\hline Oleic & 37 & 7 & 23 & 74 & 19 & 16 & 21 \\
\hline Others & 0 & 0 & 7 & 3 & 1 & 8 & 0 \\
\hline \multicolumn{8}{|l|}{ Saturated } \\
\hline$<\mathrm{C}_{16}$ & 2 & 80 & 21 & 0 & $<1$ & 0 & $<1$ \\
\hline Palmitic & $4 \overline{5}$ & 8 & 45 & 12 & 7 & 12 & 6 \\
\hline$>\mathrm{C}_{16}$ & 3 & 2 & 0 & 2 & 4 & 5 & 5 \\
\hline Iodine value & 53 & 9 & 34 & 90 & 131 & 166 & 210 \\
\hline Melting point§ & 40 & 27 & & -4 & -25 & -28 & -30 \\
\hline
\end{tabular}

* Wissenschaftliche Tabellen Geigy (1977).

$\dagger$ According to the suppliers.

\$ Raederstorff \& Moser (1992).

$\S$ For details of procedure, see p. 854.

The liquid test meals contained $(\mathrm{g} / \mathrm{kg}$ ) either starch 25 , glucose 240 , defatted milk powder 120 , plant oil 76 and $150 \mathrm{mM}-\mathrm{NaCl}$ solution 539 , or, in order to obtain an equivalent composition, starch 18, glucose 173, defatted milk powder 87, cream 333 (i.e. $76 \mathrm{~g} \mathrm{fat} / \mathrm{kg}$ ) and $\mathrm{NaCl}$ solution 389 . The fatty acid compositions of the dietary fats are given in Table 1. A stable emulsion was made by suspending the milk powder, glucose and starch in the $\mathrm{NaCl}$ solution, adding the dietary fat and blending in a glass-on-glass homogenizer for $30 \mathrm{~s} \mathrm{(} 2 \mathrm{~min}$ for cream). As described below, these test meals contained one, or more usually, two radiolabelled triacylglycerols.

After preparation the test meals were stored at $-20^{\circ}$. On the day of use they were thawed and reblended $(30 \mathrm{~s})$. On both the day of preparation and of use the stability of the emulsions and the uniform distribution of the markers were checked by measuring the radioactivity of at least five samples from different sites within the emulsion.

\section{Administration of test meals and orlistat suspensions}

The vehicle in which orlistat was dispersed contained $50 \mathrm{~g}$ gum arabic plus $50 \mathrm{~g}$ milk powder $/ 1$ in water.

The mice were divided into groups of three. After a $24 \mathrm{~h}$ fast, each mouse was orally administered about $250 \mu \mathrm{l}(10 \mathrm{ml} / \mathrm{kg}$ body weight $)$ of the liquid test meal followed directly by about $250 \mu \mathrm{l}$ of the above vehicle. Depending on the experimental design the orlistat was either dissolved in the fat of the test meal or suspended in the vehicle. Each group received a different dose of orlistat $(1,3,10,30,100$ or $1000 \mu \mathrm{mol} / \mathrm{kg}$ body weight). The mice were then given free access to their normal chow, and the faeces eliminated by each mouse during the next $31 \mathrm{~h}$ were collected. The test meals were administered at 09.00 hours, $3 \mathrm{~h}$ after the beginning of the $12 \mathrm{~h}$ day.

For the experiment shown in Fig. 1, [ $\left.{ }^{3} \mathrm{H}\right]$ triolein (about $0.0037 \mathrm{MBq} / \mathrm{ml}$ test meal) was incorporated into the dietary lipid and either $\left[1-{ }^{14} \mathrm{C}\right]$ oleic acid or $\operatorname{di}\left[1-{ }^{14} \mathrm{C}\right]$ oleoylphosphatidylcholine (about $0.0037 \mathrm{MBq} / \mathrm{ml}$ test meal) into the aqueous phase of the test meal.

The results in Tables 2 and 3 derive from two series of experiments. In the first the ${ }^{14} \mathrm{C}-$ 
radiolabelled triacylglycerols (about $0.0037 \mathrm{MBq} / \mathrm{ml}$ test meal) were incorporated into the dietary lipid and $\left[{ }^{3} \mathrm{H}\right]$ polyethyleneglycol (about $0.00074 \mathrm{MBq} / \mathrm{ml}$ test meal) was added to the aqueous phase of the test meal. This showed that during a $31 \mathrm{~h}$ collection period 91 to $102 \%$ of the nonabsorbable marker $\left[{ }^{3} \mathrm{H}\right]$ polyethyleneglycol was eliminated in the faeces. Further, it was found that at doses of orlistat sufficient to give approximately $80 \%$ inhibition of $\left[{ }^{14} \mathrm{C}\right]$ triolein absorption there was no separation of the water-soluble $\left[{ }^{3} \mathrm{H}\right]$ polyethyleneglycol from the lipid-soluble $\left[{ }^{14} \mathrm{C}\right]$ triolein during the intestinal transit. In the second series, which accounts for about half the $\mathrm{ID}_{50}$ values in Table 3 and all the results in Fig. 2, $\left[{ }^{3} \mathrm{H}\right]$ triolein (about $0.037 \mathrm{MBq} / \mathrm{ml}$ test meal) and one of the $\left[{ }^{14} \mathrm{C}\right]$ radiolabelled triacylglycerols (about $0.037 \mathrm{MBq} / \mathrm{ml}$ test meal) were incorporated into the test meals.

In the experiment described in Table 5 the mice were orally administered two liquid test meals (about $250 \mu \mathrm{l}$ ) in which olive oil was the dietary lipid. In addition, the first test meal contained both $\left[{ }^{3} \mathrm{H}\right]$ triolein and orlistat whereas the second, which was administered immediately afterwards, contained $\left[{ }^{14} \mathrm{C}\right]$ triolein alone.

\section{Measurement of radioactivity in faeces}

The ${ }^{3} \mathrm{H}$ - and ${ }^{14} \mathrm{C}$-radioactivity in the dried faeces was separated in a Packard sample oxidizer (Canberra Packard S.A., CH-8038 Zürich, Switzerland) and measured by liquid scintillation counting. The radioactivity eliminated in the faeces was expressed as a percentage of that in the test meal.

\section{Melting points}

The melting points of the dietary lipids were measured in a Mettler 2000B differential scanning calorimeter (Mettler-Toledo AG, CH-8606 Nänikon, Switzerland) (see Table 1). The samples were cooled from $22^{\circ}\left(60^{\circ}\right.$ for palm and coconut oils) to $-70^{\circ}$, and then heated at $5^{\circ} / \mathrm{min}$. The melting point was taken as the temperature at the peak of the main endothermic transition.

\section{Analysis of the data}

In the absence of a theoretical model, an exponential relationship between dose and response was assumed in which both the maximal elimination of radiolabel in the faeces $(\max )$ and the orlistat dose required for half maximal elimination of radiolabel $\left(\right.$ ID $_{50}$ ) were determinable parameters. A least-squares, nonlinear curve-fitting procedure was used to fit the parameters $\max$ and $\mathrm{ID}_{50}$ in equation 1 to the data from each experiment (e.g., Fig. 1) other than those in which the elimination of radiolabelled triacylglycerol was not approximately zero in the absence of orlistat. In the latter case the parameters max, ID $_{50}$ and $\min$ (orlistat-independent elimination of radiolabel) in equation 2 were fitted to the data. The average $\mathrm{ID}_{50}$ for a given radiolabelled triacylglycerol is the mean of these values (Table 3).

$$
\begin{aligned}
& y=\max -\max / \exp \left(0.693 x / \mathrm{ID}_{50}\right) \\
& y=\max -\max / \exp \left(0.693 x / \mathrm{ID}_{50}\right)+\min ,
\end{aligned}
$$

where $y$ is the radiolabel eliminated in the faeces (as a percentage of that administered) and $x$ is the dose of orlistat.

In experiments where the effect of orlistat on the elimination of two radiolabelled triacylglycerols was compared by giving them together, the results were also analysed by linear regression (Fig. 2).

\section{Statistics}

The results in Tables 2 and 5 are expressed as the mean, with the SEM, from the indicated number of mice. The $\mathrm{ID}_{50}$ values in Table 3 are the mean, with the SEM, from the indicated number of experiments, each of which was made on a different day. To determine an ID $_{50}$, 
three mice were used at each of, typically, three different orlistat doses. Statistical significance of differences was assessed by Student's $t$ test.

\section{RESULTS}

The experiments were designed to test the effect of orlistat, a lipase inhibitor, on the absorption of different dietary lipids (Table 1) from liquid test meals in mice. The test meals were orally administered. The orlistat was either incorporated into the meal (in meal) or administered immediately after the meal (post meal). Absorption was assessed by using radiolabelled triacylglycerols with different degrees of saturation $\left(\left[{ }^{14} \mathrm{C}\right]\right.$ tri- $\gamma$-linolenin, $\left[{ }^{3} \mathrm{H}\right]$ triolein and $\left[{ }^{14} \mathrm{C}\right]$ tripalmitin). For comparative purposes, the dietary oils have been classified as high- and low-melting-point oils (above and below $0^{\circ}$, see Table 1).

As seen from the amount of radiolabel in the faeces of untreated mice (Table 2), the absorption of $\left[{ }^{14} \mathrm{C}\right]$ tri- $\gamma$-linolenin and $\left[{ }^{3} \mathrm{H}\right]$ triolein from the tested dietary lipids was $>97 \%$ and in general lay between 98 and $99 \%$. In contrast, although the absorption of $\left[{ }^{14} \mathrm{C}\right]$ tripalmitin was $>97 \%$ when the dietary lipid was olive oil or coconut oil, it was only about $90 \%$ when the dietary lipid was cream or palm oil (Table 2). The lipase inhibitor orlistat dose-dependently inhibited the absorption of these radiolabelled triacylglycerols (e.g. $\left[{ }^{3} \mathrm{H}\right]$ triolein in Fig. 1) but not that of either $\left[{ }^{14} \mathrm{C}\right]$ oleic acid (Fernandez \& Borgström, 1989; see also Fig. 1) or of $\left[{ }^{14} \mathrm{C}\right]$ phosphatidylcholine (Fig. 1). However, the amount of orlistat required for the half-maximal inhibition of radiolabelled triacylglycerol absorption $\left(\mathrm{ID}_{50}\right)$ depended on whether the orlistat was given in the meal or immediately afterwards, on which of the radiolabelled triacylglycerols was used and, to a certain extent, on the dietary lipid (Table 3).

\section{In-meal $\mathrm{v}$. post-meal administration of orlistat}

When orlistat was given in the test meal its $\mathrm{ID}_{50}$ was about three times smaller than when it was given immediately afterwards. This difference, which was highly significant $(P=0.0001)$, was found irrespective of which of the radiolabels was used and of whether the dietary lipid had a high or low melting point (Table 3). For example, for $\left[{ }^{14} \mathrm{C}\right]$ tri- $\gamma$ linolenin the $\mathrm{ID}_{50}$ was $2-4 \mu \mathrm{mol} / \mathrm{kg}$ body weight when the orlistat was given in the test meal and $5-12 \mu \mathrm{mol} / \mathrm{kg}$ when given immediately afterwards (Table 3 ).

\section{Dependence of the determined $I D_{50}$ on the radiolabelled marker}

The $\mathrm{ID}_{50}$ for inhibiting the absorption of $\left[{ }^{3} \mathrm{H}\right]$ triolein and $\left[{ }^{14} \mathrm{C}\right]$ tripalmitin when the dietary oil had a high melting point was, for a given mode of orlistat administration, essentially the same (Table 3; the absorption of $\left[{ }^{3} \mathrm{H}\right]$ tripalmitin from test meals with low-melting-point dietary lipids was not studied). In contrast, and irrespective of the mode of orlistat administration, the $\mathrm{ID}_{50}$ for the inhibition of $\left[{ }^{3} \mathrm{H}\right]$ triolein absorption was larger than that for $\left[{ }^{14} \mathrm{C}\right]$ tri- $\gamma$-linolenin, by a factor of about 1.3 from test meals containing dietary oils with a high melting point and by a factor of about 2 from those containing oils with a low melting point (Table 3). Similarly, the $\mathrm{ID}_{50}$ for the inhibition of $\left[{ }^{14} \mathrm{C}\right]$ tripalmitin absorption from test meals containing dietary oils with a high melting point was 1.3- to 1.5-fold larger than that for $\left[{ }^{14} \mathrm{C}\right]$ tri- $\gamma$-linolenin (Table 3). These differences were significant (Table 4).

Dependence of the determined $I D_{50}$ on the dietary lipid in the test meal

The $\mathrm{ID}_{50}$ for the inhibition of $\left[{ }^{3} \mathrm{H}\right]$ triolein absorption was not affected by the melting point of the dietary lipid, neither was that of $\left[{ }^{14} \mathrm{C}\right]$ tri- $\gamma$-linolenin when the orlistat was given after the test meal (Table 3). However, when orlistat was given in the meal, the $\mathrm{ID}_{50}$ for $\left[{ }^{14} \mathrm{C}\right]$ tri$\gamma$-linolenin was about 1.5 -fold larger from test meals containing lipids with higher as opposed to lower melting points $(P=0.012$, Table 3$)$. 
Table 2. Effect of dietary lipid type on the loss of $\left[{ }^{14} \mathrm{C}\right]$ tri- $\gamma$-linolenin, $\left[{ }^{3} \mathrm{H}\right]$ triolein and

$\left[{ }^{14}\right.$ C]tripalmitin in faeces of control mice*

(Mean values with their standard errors)

\begin{tabular}{|c|c|c|c|c|c|c|c|c|c|}
\hline \multirow{2}{*}{$\begin{array}{c}\text { Faecal loss } \\
\text { (expressed as } \% \text { intake)... }\end{array}$} & \multicolumn{3}{|c|}{$\left[{ }^{14} \mathrm{C}\right]$ trilinolenin } & \multicolumn{3}{|c|}{$\left[{ }^{3} \mathrm{H}\right]$ triolein } & \multicolumn{3}{|c|}{$\left[{ }^{14} \mathrm{C}\right]$ tripalmitin } \\
\hline & $n$ & Mean & $\mathbf{S E}$ & $n$ & Mean & $\mathrm{SE}$ & $n$ & Mean & SE \\
\hline Palm oil & 23 & $1 \cdot 7$ & 0.1 & 39 & $2 \cdot 8$ & $0 \cdot 2$ & 22 & $9 \cdot 7$ & $0 \cdot 8$ \\
\hline Coconut oil & 12 & $1 \cdot 4$ & 0.1 & 18 & $1 \cdot 4$ & $0 \cdot 1$ & 12 & $2 \cdot 7$ & 0.7 \\
\hline Cream & 3 & $1 \cdot 1$ & 0.1 & 9 & $1 \cdot 7$ & 0.2 & 6 & $9 \cdot 0$ & $1 \cdot 5$ \\
\hline Olive oil & 3 & 1.9 & $0 \cdot 1$ & 9 & 0.7 & 0.4 & 3 & $1 \cdot 3$ & $0 \cdot 2$ \\
\hline Sunflower-seed oil & 6 & $1 \cdot 3$ & $0 \cdot 2$ & 3 & 0.9 & 0.0 & & & \\
\hline Borage oil & 6 & $2 \cdot 1$ & 0.1 & 6 & $2 \cdot 2$ & 0.2 & & & \\
\hline Linseed oil & 2 & $1 \cdot 0$ & $0 \cdot 1$ & 5 & 1.6 & 0.1 & & & \\
\hline
\end{tabular}

* For details of procedures, see pp. 852-854.

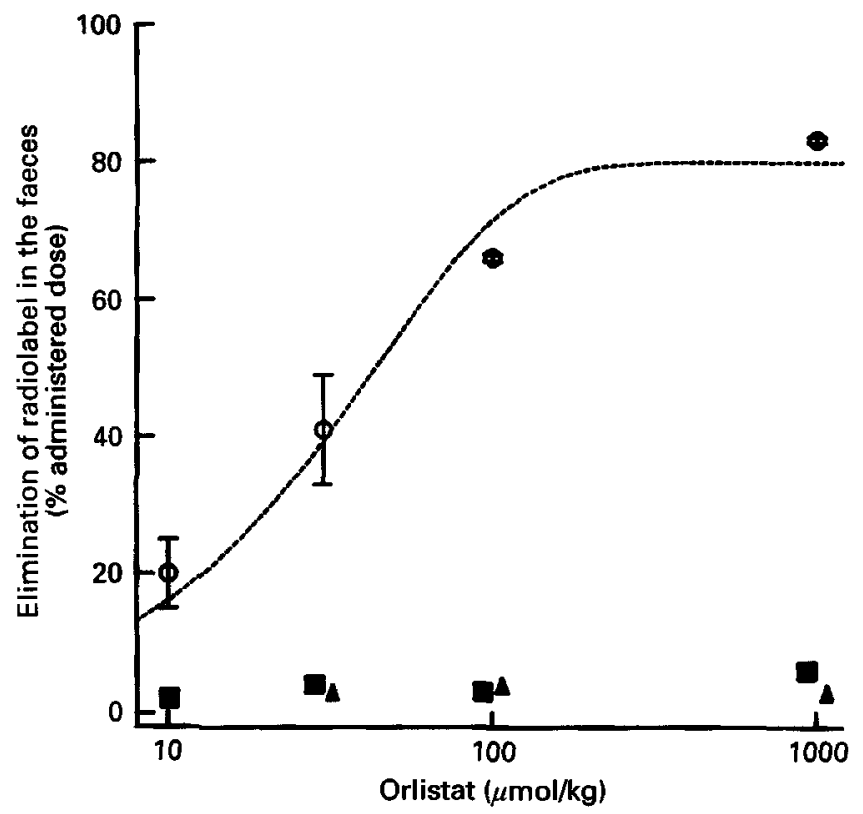

Fig. 1. Effect of the lipase inhibitor orlistat on the elimination of $\left[{ }^{8} \mathrm{H}\right]$ triolein $(\mathrm{O}),\left[{ }^{14} \mathrm{C}\right]$ phosphatidylcholine ( $\left.\boldsymbol{\square}\right)$ and $\left[{ }^{14} \mathrm{C}\right]$ oleic acid $(\boldsymbol{A})$ in the faeces of mice. Each mouse was given one of two test meals by oral administration. These contained olive oil and either $\left[{ }^{3} \mathrm{H}\right]$ triolein plus $\left[{ }^{14} \mathrm{C}\right]$ phosphatidylcholine or $\left[{ }^{3} \mathrm{H}\right]$ triolein plus $\left[{ }^{14} \mathrm{C}\right]$ oleic acid. The orlistat was given immediately afterwards by oral administration. At each dose, each of the test meals was given to three mice. Values are means for six observations for $\left[{ }^{3} \mathrm{H}\right]$ triolein and three observations for both $\left[{ }^{14} \mathrm{C}\right]$ phosphatidylcholine and $\left[{ }^{14} \mathrm{C}\right]$ oleic acid. For details of test meals, see pp. 852-854.

\section{Direct comparison of the absorption of two radiolabelled triacylglycerols from the same test meal}

${ }^{3} \mathrm{H}$ - and ${ }^{14} \mathrm{C}$-radiolabelled triacylglycerols were incorporated into the same test meal in order to eliminate any variations in the sensitivity of individual mice to the effect of orlistat on triacylglycerol absorption. The data were plotted as the percentage of the ${ }^{14} \mathrm{C}$-radiolabel recovered in the faeces against that of the ${ }^{3} \mathrm{H}$-radiolabel, irrespective of the orlistat dose. The elimination of $\left[{ }^{14} \mathrm{C}\right]$ triolein plotted against that of $\left[{ }^{3} \mathrm{H}\right]$ triolein had, as expected, a slope 


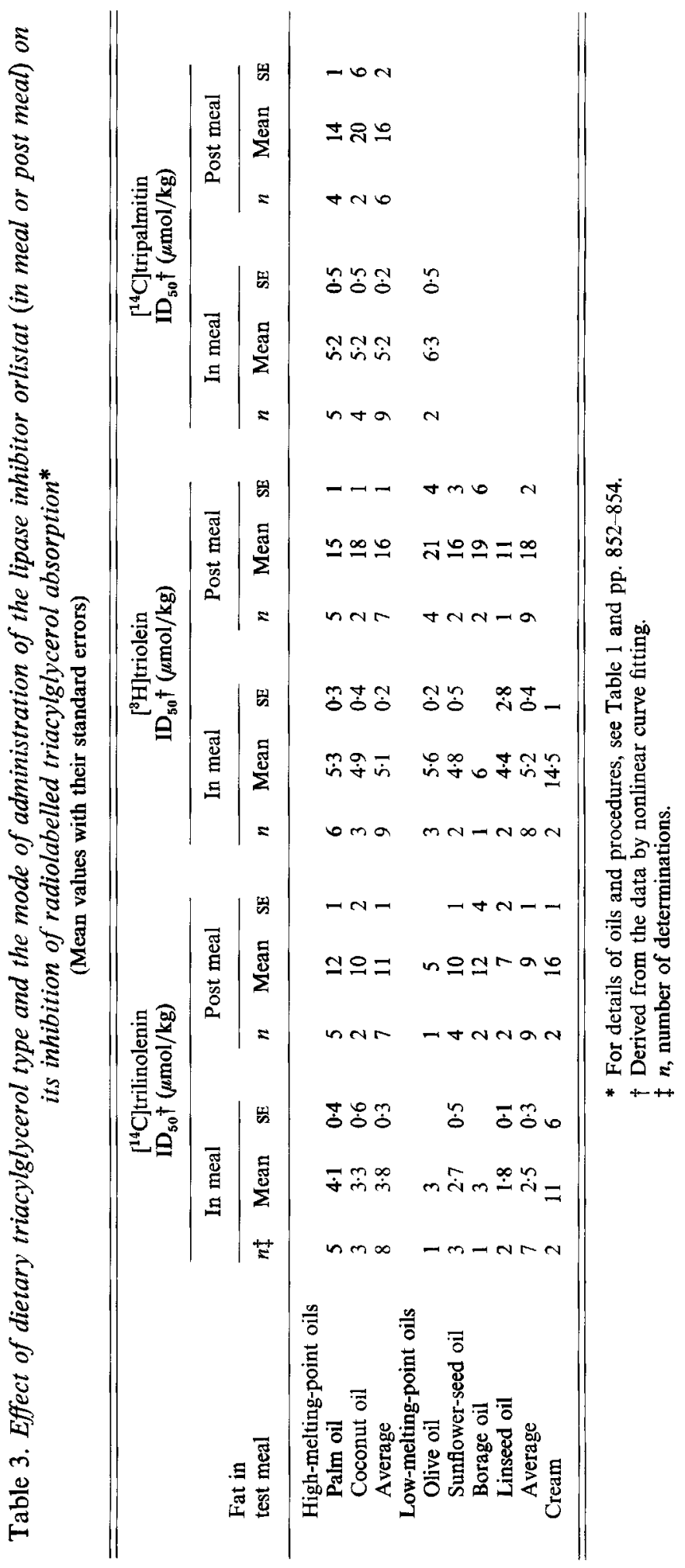



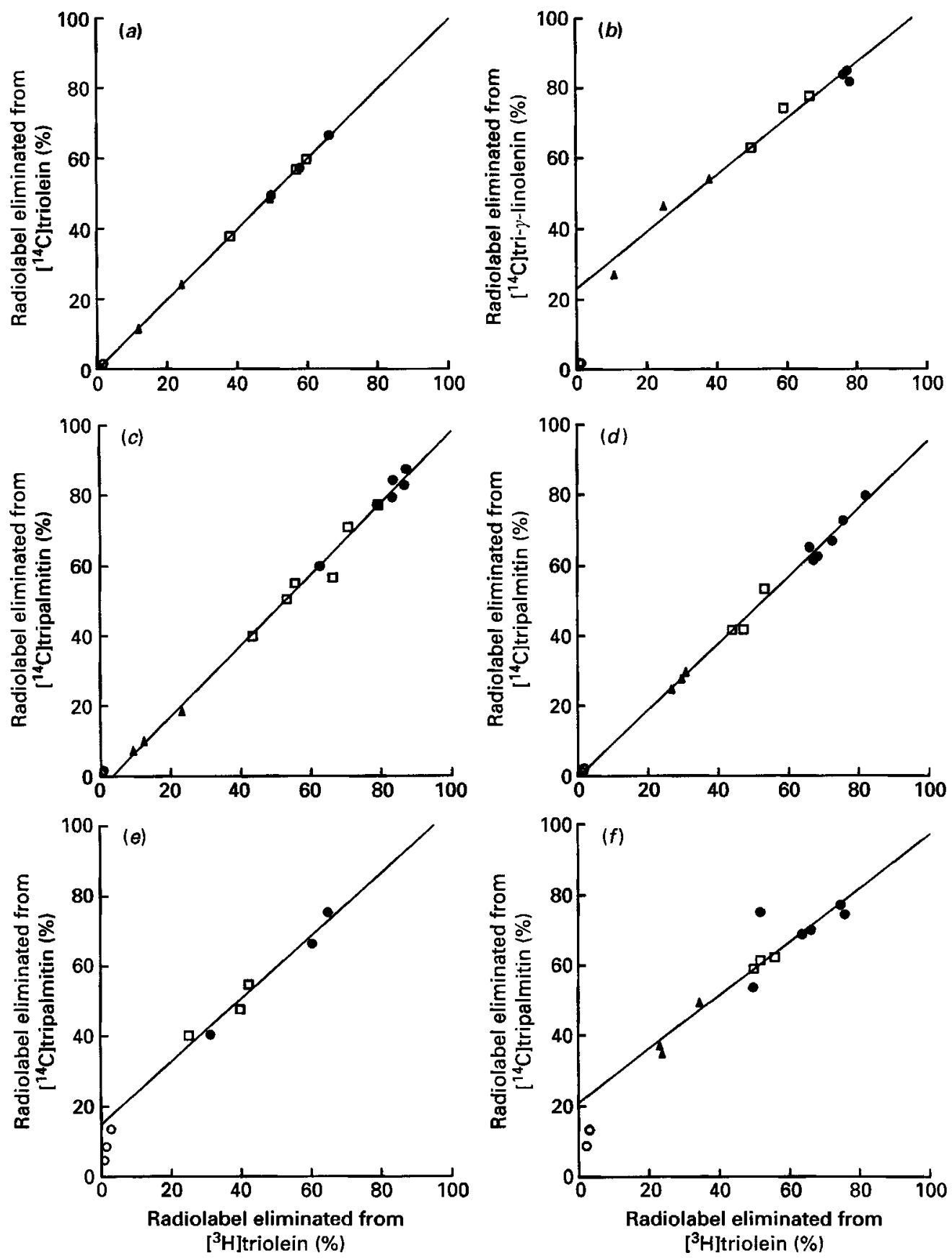

Fig. 2. Comparison of the effect of the lipase inhibitor orlistat on the elimination in the faeces of $\left[{ }^{14} \mathrm{C}\right] \mathrm{tri}-\gamma$ linolenin, $\left[{ }^{14} \mathrm{C}\right]$ tripalmitin and $\left[{ }^{14} \mathrm{C}\right]$ triolein with that of $\left[{ }^{3} \mathrm{H}\right]$ triolein from test meals containing different lipids. The mice were orally administered a test meal containing orlistat and $\left[{ }^{3} \mathrm{H}\right]$ triolein with $\left[{ }^{14} \mathrm{C}\right]$ triolein $(\mathrm{a}),\left[{ }^{14} \mathrm{C}\right] \mathrm{tri}-\gamma$ linolenin (b) or $\left[{ }^{14} \mathrm{C}\right]$ tripalmitin $(\mathrm{c}-\mathrm{f})$. The orlistat and the radiolabelled triacylglycerols were dissolved in olive oil $(a-c)$, coconut oil (d), cream (e) or palm oil (f). The orlistat was given at $0(O), 3(\boldsymbol{A}), 10(\square)$ and $30(\bullet) \mu \mathrm{mol} / \mathrm{kg}$ body weight. Each value is from one mouse. The values from the control mice $(O)$ were excluded from the linear regressions. Parameters derived from these regressions are given at the foot of the opposite page. 
Table 4. Significance of the effect of the fatty acid composition of radiolabelled triacylglycerols on the ability of orlistat to inhibit their absorption

\begin{tabular}{|c|c|c|c|}
\hline & $\begin{array}{c}{\left[{ }^{14} \mathrm{C}\right] \text { trilinolenin }} \\
\text { v. }\left[{ }^{3} \mathrm{H}\right] \text { triolein } \\
P\end{array}$ & 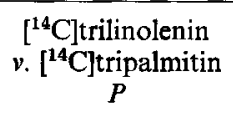 & $\begin{array}{c}{\left[{ }^{3} \mathrm{H}\right] \text { triolein } v} \\
{\left[{ }^{14} \mathrm{C}\right] \text { tripalmitin }} \\
P\end{array}$ \\
\hline $\begin{array}{l}\text { In high-melting-point oil } \\
\text { In meal } \\
\text { Post meal } \\
\text { In low-melting-point oil } \\
\text { In meal } \\
\text { Post meal }\end{array}$ & $\begin{array}{l}0.006 \\
0.001 \\
\\
0.0001 \\
0.001\end{array}$ & $\begin{array}{l}0.015 \\
0.021\end{array}$ & $\begin{array}{l}0.917 \\
0.913\end{array}$ \\
\hline
\end{tabular}

Table 5. Comparison of the orlistat-induced loss of radiolabelled triolein in the faeces of mice when the orlistat and the radiolabel are given in the same or different test meals*

(Mean values with their standard errors for three mice)

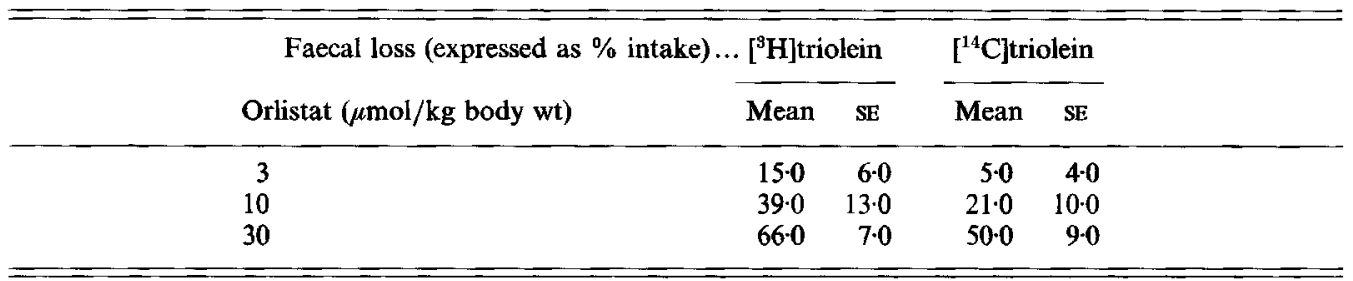

* Each mouse was orally administered two test meals, one after the other. Both test meals, which contained olive oil as the dietary lipid, had the same composition except that, in addition, the first contained orlistat plus $\left[{ }^{3} \mathrm{H}\right]$ triolein and the second $\left[{ }^{14} \mathrm{C}\right]$ triolein. For further details, see p. 854.

of unity and an intercept of approximately zero (Fig. 2a). However, a plot of $\left[{ }^{14} \mathrm{C}\right] \mathrm{tri}-\gamma-$ linolenin against $\left[{ }^{3} \mathrm{H}\right]$ triolein was apparently curvilinear, in that although the elimination of both radiolabels was $<2 \%$ in the absence of orlistat (Table 2), in its presence the elimination of $\left[{ }^{14} \mathrm{C}\right]$ tri- $\gamma$-linolenin was up to $20 \%$ larger than that of $\left[{ }^{3} \mathrm{H}\right]$ triolein (Fig. $2 \mathrm{~b}$ ). Plots of the elimination of $\left[{ }^{14} \mathrm{C}\right]$ tripalmitin against $\left[{ }^{3} \mathrm{H}\right]$ triolein were also linear (Fig. $2 \mathrm{c}-\mathrm{f}$ ). When the dietary lipid was olive oil or coconut oil the slope was about 1 and the intercept close to zero (Fig. $2 \mathrm{c}$ and d). In contrast, when the dietary lipid was cream or palm oil the slopes were less than unity ( 0.89 and 0.76 respectively) and there were intercepts of 15 and $21 \%$ respectively, on the $\left[{ }^{14} \mathrm{C}\right]$ tripalmitin axis (Fig. $2 \mathrm{e}$ and $\mathrm{f}$ ). These intercepts (see legend

Fig. 2 (cont.)

\begin{tabular}{ccccccc} 
Figure & Slope & SD & $\begin{array}{c}\text { Intercept } \\
(\%)\end{array}$ & $\begin{array}{c}\text { Confidence } \\
\text { limits } 95 \%\end{array}$ \\
\hline a & $1 \%)$ & $(\%)$ \\
\hline b & 0.80 & 0.01 & -0.1 & -1 & 1 \\
c & 1.01 & 0.03 & -3 & -16 & 30 \\
d & 0.95 & 0.03 & -0.4 & -5 & 1 \\
e & 0.89 & 0.09 & 15 & 4 & 26 \\
f & 0.76 & 0.09 & 21 & 7 & 35 \\
\hline
\end{tabular}


to Fig. 2) were higher than the level of $\left[{ }^{14} \mathrm{C}\right]$ tripalmitin elimination found in mice that were not treated with orlistat (Table 2).

\section{In-meal v. extra-meal administration of orlistat}

When mice were administered a test meal that contained orlistat plus $\left[{ }^{3} \mathrm{H}\right]$ triolein and then, immediately afterwards, a second that contained $\left[{ }^{14} \mathrm{C}\right]$ triolein alone, the elimination of the $\left[{ }^{3} \mathrm{H}\right]$ triolein was consistently larger than that of the $\left[{ }^{14} \mathrm{C}\right]$ triolein (Table 5). This is in contrast to the results shown in Fig. $2 \mathrm{a}$, which show that when both radiolabels were incorporated into the same test meal orlistat inhibited their absorption to the same extent.

\section{DISCUSSION}

As triacylglycerol absorption is usually complete, it is difficult to assess in vivo whether the substrate specificity of gastrointestinal lipases is the same for all triacylglycerols. In order to assess this, under reasonably physiological conditions, we tested the effect of orlistat on the absorption of three very different radiolabelled triacylglycerols (tripalmitin, triolein and tri- $\gamma$-linolenin) from a variety of plant oils as well as from cream. The dietary lipids were chosen to give a spectrum of fatty acid compositions, iodine values and melting points similar to that of the triacylglycerols found in the human diet (Table 1). The radiolabels were chosen to represent saturated, unsaturated and highly unsaturated dietary triacylglycerols. However, this choice was determined by availability rather than resemblance to naturally occurring triacylglycerols. The only advantage of triacylglycerols that are uniformly substituted with the same fatty acid is the simplicity of their synthesis, which leads directly to chemically defined molecules. The term triacylglycerol absorption, although not strictly correct, is a convenient description for the overall process of triacylglycerol hydrolysis and the subsequent absorption of the liberated fatty acids and monoacylglycerols. It is especially convenient as in vivo the two underlying processes are difficult to observe separately. However, as orlistat inhibits triacylglycerol hydrolysis and not fatty acid absorption (Fernandez \& Borgström, 1989; see also Fig. 1), an orlistatinduced increase in radiolabel in the faeces from radiolabelled dietary triacylglycerols should mainly monitor its effect on triacylglycerol hydrolysis.

In the absence of orlistat, radiolabelled tri- $\gamma$-linolenin and triolein were almost completely absorbed $(>97 \%$ ) by mice from all the dietary fats (Table 2$)$. However, the absorption of radiolabelled tripalmitin depended on the oil; it was about $99 \%$ when the dietary lipid was olive oil, about $97 \%$ when it was coconut oil and about $90 \%$ when it was cream or palm oil (Table 2). This is not usually observed (Bonanome \& Grundy, 1988) and may result from the faster gastrointestinal transit after oral administration of a liquid test meal than after eating a normal meal (after $7 \mathrm{~h}$ we found $>90 \%$ of the nonabsorbable marker, $\left[{ }^{3} \mathrm{H}\right]$ polyethyleneglycol, in the faeces following an orally administered meal as opposed to about $60 \%$ following a normal meal). Previous studies in rats have shown that both palmitic and stearic acids require a greater length of intestine for their absorption than do linoleic and oleic acids (Ockner et al. 1972; Bergstedt et al. 1990) and, further, that the absorption of palmitic acid is more easily decreased than that of linoleic by increasing the palmitic acid load (Ockner et al. 1972). However, the present results do not distinguish between incomplete hydrolysis of tripalmitin and incomplete absorption of palmitic acid.

A least-squares, nonlinear curve-fitting procedure was used to derive an $\mathrm{ID}_{50}$ for the inhibition of triacylglycerol absorption from the data. In the absence of a theoretical model an exponential relationship between dose and response was assumed in which both the maximal level of inhibition and the $\mathrm{ID}_{50}$ were determinable parameters (see equations 1 and 
2). Using equation 1 or, where the radiolabel was eliminated in the faeces in the absence of orlistat, equation 2, the maximal inhibition was found to be approximately $80 \%$ (e.g. Fig. 1). Neither the nature of the radiolabelled triacylglycerol nor that of the dietary fat appeared to influence this value. One explanation for the maximal inhibition being less than $100 \%$ is that before orlistat can bind covalently to the lipase it has to compete with the dietary triacylglycerol for access to the substrate binding site. However, this is unlikely to be the only factor, as the maximal elimination of dietary triacylglycerol does not depend on the amount of triacylglycerol in the test meal (D. Isler, unpublished results).

The dose of orlistat required to decrease absorption to $50 \%\left(\mathrm{ID}_{50}\right)$ of the extrapolated maximal value was between 2 and 4 times larger when the orlistat was given after the test meal compared with when it was dissolved in the lipids of the test meal (Table 3). Evidently, while in the stomach, orlistat suspended in a $50 \mathrm{~g}$ gum arabic plus $50 \mathrm{~g}$ milk-powder $/ 1$ vehicle does not fully incorporate into the dietary lipids of the test meal we used. A possible explanation is that the low solubility of orlistat in water retards its transfer into the lipid phase containing the radiolabelled marker. We also found, when a test meal containing $\left[{ }^{3} \mathrm{H}\right]$ triolein plus orlistat was administered immediately before a test meal containing only $\left[{ }^{14} \mathrm{C}\right]$ triolein, that the absorption of $\left[{ }^{14} \mathrm{C}\right]$ triolein was less inhibited than that of $\left[{ }^{3} \mathrm{H}\right]$ triolein (compare the results in Table 5 with those in Fig. 2a). Evidently, the complete equilibration of components between different lipid phases in the stomach does not always occur.

The $\mathrm{ID}_{50}$ for the inhibition of lipase activity by orlistat cannot depend on the radiolabelled triacylglycerol as this is present only in trace amounts. Therefore, as the $\mathrm{ID}_{50}$ for the inhibition of radiolabelled triolein absorption is higher than that of tri- $\gamma$-linolenin (Table 3), it follows that triolein is a better substrate for gastrointestinal lipases than tri$\gamma$-linolenin. This is consistent with the results of Lawson \& Hughes (1988) who found, in vitro, that pancreatic lipase was less efficient at hydrolysing $\gamma$-linolenic acid than $\alpha$-linolenic acid, and most other fatty acids, from plant triacylglycerols. The effect of orlistat on the absorption of $\gamma$-linolenic acid is therefore not representative of its effect on the absorption of essential and polyunsaturated fatty acids in general. The ID $_{50}$ for the inhibition of radiolabelled triolein absorption is independent of the melting point of the dietary lipid and of whether the orlistat is given after the test meal or dissolved in the lipids of the test meal (Table 3). The same is true for tri- $\gamma$-linolenin when administered after the test meal, but when it is dissolved in the lipids of the test meal the $\operatorname{ID}_{50}$ is slightly smaller if they have a low, as opposed to a high, melting point $(2.5$ v. $3 \cdot 8, P=0.012$, Table 3$)$.

It is generally assumed that radiolabelled triacylglycerols are best as markers for those triacylglycerols they most resemble. However, the extent to which radiolabelled triacylglycerols that contain a single fatty acid species resemble and report on dietary triacylglycerols is not known. Our results show that the absorption of $\left[{ }^{14} \mathrm{C}\right]$ tri- $\gamma$-linolenin is more easily inhibited by orlistat than is that of $\left[{ }^{14} \mathrm{C}\right]$ triolein (Fig. 2 and Table 3 ), and that under certain conditions although the absorption of $\left[{ }^{14} \mathrm{C}\right]$ triolein and $\left[{ }^{14} \mathrm{C}\right]$ tri- $\gamma$-linolenin is complete, that of $\left[{ }^{14} \mathrm{C}\right]$ tripalmitin is about $90 \%$ (Fig. $2 \mathrm{e}$ and $\mathrm{f}$ and Table 2).

In conclusion, orlistat can be used to investigate triacylglycerol hydrolysis and absorption under physiological conditions in the intact animal and may therefore provide a useful tool to elucidate the different processes that occur in fat absorption.

\section{REFERENCES}

Barbier, P. \& Schneider, F. (1987). Synthesis of tetrahydrolipstatin and absolute configuration of tetrahydrolipstatin and lipstatin. Helvetica Chimica Acta 70, 196-202.

Bergstedt, S. E., Bergstedt, J. L., Fujimoto, K., Mansbach, C., Kritchevsky, D. \& Tso, P. (1991). Effects of glycerol tripalmitate and glycerol trioleate on intestinal absorption of glycerol tristearate. American Journal of Physiology 261, G239-G247. 
Bergstedt, S. E., Hayashi, H., Kritchevsky, D. \& Tso, P. (1990). A comparison of absorption of glycerol tristearate and glycerol trioleate by rat small intestine. American Journal of Physiology 259, G386-G393.

Bonanome, A. \& Grundy, S. M. (1988). Effect of dietary stearic acid on plasma cholesterol and lipoprotein levels. New England Journal of Medicine 318, 1244-1248.

Borgström, B. (1988). Mode of action of tetrahydrolipstatin: a derivative of the naturally occurring lipase inhibitor lipstatin. Biochimica et Biophysica Acta 962, 308-316.

Brockerhoff, H. (1970). Substrate specificity of pancreatic lipase. Influences of the structure of fatty acids on the reactivity of esters. Biochimica et Biophysica Acta 212, 92-101.

Carey, M. C., Small, D. M. \& Bliss, C. M. (1983). Lipid digestion and absorption. Annual Review of Physiology 45, $651-678$.

Chen, Q., Sternby, B. \& Nilsson, A. (1989). Hydrolysis of triacylglycerol arachidonic and linoleic acid ester bonds by human pancreatic lipase and carboxyl ester lipase. Biochimica et Biophysica Acta 1004, 372-385.

Drent, M. L., Von Bergmann, K., Quaade, F., Sjöström, L., Strobel, W. \& Van der Veen, E. A. (1992). Multiple dose study with orlistat in obese patients. Intemational Journal of Obesity 16, Suppl 1, 16.

Fernandez, E. \& Borgström, B. (1989). Effect of tetrahydrolipstatin, a lipase inhibitor, on absorption of fat from the intestine of the rat. Biochimica et Biophysica Acta 1001, 249-255.

Hadváry, P. Lengsfeld, H. \& Wolfer, H. (1988). Inhibition of pancreatic lipase in vitro by the covalent inhibitor tetrahydrolipstatin. Biochemical Journal 256, 357-361.

Hadváry, P., Sidler, W., Meister, W., Vetter, W. \& Wolfer, H. (1991). The lipase inhibitor tetrahydrolipstatin binds covalently to the putative active site serine of pancreatic lipase. Journal of Biological Chemistry 266 , 2021-2027.

Hauptmann, J. B., Jeunet, F. S. \& Hartmann, D. (1992). Initial studies in humans with the novel gastrointestinal lipase inhibitor Ro 18-0647 (tetrahydrolipstatin). American Journal of Clinical Nutrition 55, 309S-313S.

Hogan, S., Fleury, A., Hadváry, P., Lengsfeld, H., Meier, M. K., Triscari, J. \& Sullivan, A. C. (1987). Studies on the antiobesity activity of tetrahydrolipstatin, a potent and selective inhibitor of pancreatic lipase. International Journal of Obesity 11, Suppl. 3, 35-42.

Lawson, L. D. \& Hughes, B. G. (1988). Triacylglycerol structure of plant and fungal oils containing $\gamma$-linolenic acid. Lipids 23, 313-317.

Lüthi-Peng, Q., Märki, H. P. \& Hadváry, P. (1992). Identification of the active-site serine in human pancreatic lipase by chemical modification with tetrahydrolipstatin. FEBS Letters 229, 111-115.

Meier, M. K., Blum-Kählin, D., Bremer, K., Isler, D., Joly, P., Keller-Rupp, P. \& Lengsfeld, H. (1991). Preclinical profile of the lipase inhibitor tetrahydrolipstatin (Ro 18-0647, THL), a potential drug for the treatment of obesity. International Journal of Obesity 15, Suppl. 1, 31.

Nelson, G. J. \& Ackman, R. G. (1988). Absorption and transport of fat in mammals with emphasis on N-3 polyunsaturated fatty acids. Lipids 23, 1005-1014.

Ockner, R. K., Pittman, J. P. \& Yager, J. L. (1972). Differences in the intestinal absorption of saturated and unsaturated long chain fatty acids. Gastroenterology 62, 981-992.

Raederstorff, D. \& Moser, U. (1992). Borage or primrose oil added to standardized diets are equivalent sources for $\gamma$-linolenic acid in rats. Lipids 27, 1018-1023.

Rieke, R. D. \& Bales, S. E. (1974). Activated metals. IV. Preparation and reactions of highly reactive magnesium metal. Journal of the American Chemical Society 96, 1775-1781.

Wissenschaftlische Tabellen Geigy (1977). Teilband Körperflüssigkeiten, 8te Auflage, Basel: Ciba-Geigy AG.

Yang, L.-Y., Kuksis, A. \& Myher, J. J. (1990). Lipolysis of menhaden oil triacylglycerols and the corresponding fatty acid alkyl esters by pancreatic lipase in vitro; a reexamination. Journal of Lipid Research 31, $137-148$. 